\title{
PURIFICATION AND PROPERTIES OF TRANSKETOLASE FROM PIG LIVER \\ I. AN ATTEMPT TO RESOLVE THE ENZYME INTO APOENZYME AND COFACTORS
}

\author{
Isao Tomita, Shin-ichi SaItou, and Masaaki IshIKawA ${ }^{1}$ \\ Shizuoka College of Pharmaceutical Sciences, \\ Oshika, Shizuoka 422, Japan
}

(Received January 29, 1979)

\begin{abstract}
Summary Transketolase, sedoheptulose-7-phosphate: D-glyceraldehyde-3-phosphate glycolaldehyde-transferase [EC 2.2.1.1], was extracted from pig liver and purified 96 -fold by ammonium sulfate fractionation, followed by column chromatography using DEAE-cellulose and a Sephadex G-200. Transketolase from pig liver was stable at $\mathrm{pH} 6.0$ and above, whereas it was unstable at lower $\mathrm{pH}$ values. It could be resolved into apoenzyme and thiamine pyrophosphate in an acidic medium, in contrast to baker's or brewer's yeast transketolase which resolved in an alkaline solution. All the activity of pig liver transketolase was lost upon incubation at $\mathrm{pH} 5.0$ for two hours even at $0^{\circ} \mathrm{C}$ but about $40 \%$ of the original activity could be restored by the addition of excess thiamine pyrophosphate and $\mathrm{CaCl}_{2}$. Restoration of the activity was achieved effectively at $\mathrm{pH}$ 7.6-8.0.

Keywords transketolase, pig liver, purification, property, stability, resolution, reconstitution
\end{abstract}

Transketolase [EC 2.2.1.1] plays an important role in the metabolism of pentose by producing ribose for nucleic acid synthesis and NADPH for the synthesis of fatty acids and steroids. Transketolase purified from baker's or brewer's yeast has a molecular weight of $100,000-140,000(1,2)$ and dissociates into two identical subunits of a molecular weight of $50,000-70,000(2,3)$. It contains thiamine pyrophosphate(TPP) as a coenzyme(4) and coexists with glyceraldehyde-3phosphate dehydrogenase[EC 1.2.1.12], a functionally related enzyme $(2,5)$. Transketolase from yeasts is known to release TPP and metal ions, such as $\mathrm{Mg}^{2+}$, on alkaline treatment and the resolved enzyme can be reconstituted to a holoenzyme by incubation with TPP and a divalent cation (6-8).

1 富田 勲, 斉藤慎一, 石川雅章 
Transketolase has been purified from rat liver(9), pig liver and human erythrocytes (11) but compared to that from yeasts, transketolase from mammals has not been fully studied and information about its properties in resolution has only been obtained with rat liver. The present study describes an attempt to resolve transketolase from pig liver and presents evidence that the way in which the resolved enzyme associates with cofactors is different from that in the yeast enzyme.

\section{MATERIALS AND METHODS}

Chemicals. TPP, glycylglycine and 2-mercaptoethanol were purchased from Tokyo Kasei Kogyo Co., Ltd. and NADH and NAD were from Oriental Yeast Co., Ltd. Glyceraldehyde-3-phosphate (as barium diethylacetal), triose phosphate isomerase [EC 5.3.1.1] and glycerol-3-phosphate dehydrogenase [EC 1.1.99.5] mixture and glyceraldehyde-3-phosphate dehydrogenase [EC 1.2.1.12] were products of Boehringer-Mannheim Corp. Acrylamide, bisacrylamide and $N, N, N^{\prime}, N^{\prime}$,tetramethylethylenediamine were obtained from Seikagaku Kogyo Co., Ltd. Amide Black 10B and DEAE-cellulose were purchased from E. Merck and Brown Co., respectively. The Sephadex G-200 and Sephadex G-25 were from Pharmacia Fine Chemicals. A pentose-5-phosphate mixture was prepared from barium ribose-5phosphate with ribose-5-phosphate isomerase[EC 5.3.1.6] and xylulose-5phosphate epimerase [EC 5.1.3.1] by the method of JOHNSON and GUBLER (12). Both ribose-5-phosphate isomerase and xylulose-5-phosphate epimerase were prepared from calf spleen according to the method of AsHwell and Hickman (13). All other chemicals were of special grade from commercial sources.

Purification of transketolase. Fresh pig liver was kept at $-20^{\circ} \mathrm{C}$ until used. The frozen pig liver $(100 \mathrm{~g})$ was thawed, minced and homogenized in an ice-cold Waring blender for $5 \mathrm{~min}$ in $500 \mathrm{ml}$ of $10 \mathrm{~mm}$ Tris- $\mathrm{HCl}$ buffer ( $\mathrm{pH} \mathrm{7.6).} \mathrm{The} \mathrm{homogenate} \mathrm{was}$ centrifuged at $4^{\circ} \mathrm{C}$ with a refrigerated centrifuge (Tominaga, model S-62) for $20 \mathrm{~min}$ at $12,000 \times g$ and the resulting supernatant was used for the purification of transketolase. Solid ammonium sulfate was added to the supernatant to obtain $50 \%$ saturation and the mixture was centrifuged for $20 \mathrm{~min}$ at $12,000 \times g$. Solid ammonium sulfate was again added to the resulting supernatant to obtain $60 \%$ saturation. The precipitate $(50-60 \%$ ammonium sulfate-saturated fraction) which was obtained by centrifugation at $12,000 \times g$ was dissolved in about $10 \mathrm{ml}$ of $5 \mathrm{~mm}$ potassium phosphate buffer $(\mathrm{pH} 7.6)$ and dialyzed against two liters of the same buffer at $4^{\circ} \mathrm{C}$ for $14 \mathrm{hr}$. The dialyzate containing approximately $500 \mathrm{mg}$ of protein was applied to a DEAE-cellulose column $(3.5 \times 15 \mathrm{~cm})$ equilibrated with $5 \mathrm{~mm}$ potassium phosphate buffer $(\mathrm{pH}$ 7.6) and eluted by the same phosphate buffer at a flow rate of $60 \mathrm{ml} / \mathrm{hr}$. The eluate was collected in $5 \mathrm{ml}$ fractions with a fraction collector (Toyo, model SF-160K) and fractions 19-27 containing transketolase activity were combined. Solid ammonium sulfate was added to the combined eluate to obtain a fraction of $50-70 \%$ ammonium sulfate saturation in the same way as mentioned above. The precipitate was dissolved in a small amount of $5 \mathrm{~mm}$ 
potassium phosphate buffer $(\mathrm{pH}$ 7.6). Five $\mathrm{ml}$ of the solution containing about $100 \mathrm{mg}$ of protein was applied to a Sephadex G-200 column $(5 \times 100 \mathrm{~cm})$ equilibrated with $5 \mathrm{~mm}$ potassium phosphate buffer $(\mathrm{pH}$ 7.6). An upward elution was made with the same phosphate buffer at a flow rate of $48 \mathrm{ml} / \mathrm{hr}$. The eluate was collected in $3 \mathrm{ml}$ fractions with the fraction collector.

Acrylamide disc gel electrophoresis. Acrylamide disc gel electrophoresis was used routinely to follow the progress of purification. Electrophoresis was performed according to the technique of DAvis (14) with $50 \mathrm{~mm}$ Tris $-0.38 \mathrm{M}$ glycine buffer ( $\mathrm{pH}$ 9.5). Bromophenol blue was used as a tracking dye. Electrophoresis was carried out at a constant current of two $\mathrm{mA}$ per tube. The gels were stained with Amide Black 10B $(1 \%$ in $7 \% \mathrm{v} / \mathrm{v}$ acetic acid) and destained in $7 \% \mathrm{v} / \mathrm{v}$ acetic acid.

Determination of transketolase activity. Transketolase activity was determined spectrophotometrically by coupling the enzyme with triose phosphate isomerase and glycerol-3-phosphate dehydrogenase (4). To a quartz cuvette with a $1.0 \mathrm{~cm}$ light path were added $0.1 \mathrm{ml}$ of $0.5 \mathrm{M}$ glycylglycine buffer $(\mathrm{pH} 7.6), 50 \mu \mathrm{l}$ of $18 \mathrm{mM} \mathrm{CaCl}_{2}$, $50 \mu \mathrm{l}$ of $20 \mathrm{~mm}$ TPP and appropriate amounts of the enzyme. Distilled water was added to make up a total volume of $0.8 \mathrm{ml}$. After the mixture was incubated at $37^{\circ} \mathrm{C}$ for $20 \mathrm{~min}, 50 \mu \mathrm{l}$ of $2 \mathrm{~mm} \mathrm{NADH}$, the triose phosphate isomerase and glycerol-3phosphate dehydrogenase mixture ( $20 \mu \mathrm{g}$ of protein) and $50 \mu \mathrm{l}$ of $60 \mathrm{~mm}$ pentose-5phosphate mixture were added with gentle mixing and an addition of distilled water made up a total volume of $1.0 \mathrm{ml}$. A decrease in the absorbancy of NADH at $340 \mathrm{~nm}$ was recorded at $37^{\circ} \mathrm{C}$ using a Hitachi spectrophotometer (model 139) equipped with a temperature-controlled cell attachment (model 139-0880). The amount of protein was determined by the method of LOWRY et al.(15), using crystalline bovine serum albumin (The Armour Laboratories) as a standard.

Determination of the amount of resolved transketolase and holotransketolase. Transketolase activity determined in the presence of excess TPP and $\mathrm{CaCl}_{2}$ represents the total activity of the resolved enzyme and holoenzyme. Activity without added TPP and $\mathrm{CaCl}_{2}$ is that of the holoenzyme. The ratio of resolved enzyme and of holoenzyme to total enzyme will thus be calculated as follows:

$$
\begin{array}{r}
\text { Ratio of resolved enzyme }=\frac{A-B}{A} \times 100(\%) \\
\text { Ratio of holoenzyme }=\frac{B}{A} \times 100(\%)
\end{array}
$$

where $A$ represents the enzyme activity with TPP and $\mathrm{CaCl}_{2}$, and $B$ repersents the enzyme activity without the cofactors.

Determination of glyceraldehyde-3-phosphate dehydrogenase. Glyceraldehyde-3phosphate dehydrogenase activity was determined by measuring the reduction of NAD at $25^{\circ} \mathrm{C}$. An increase in absorbance at $366 \mathrm{~nm}$ was recorded. The standard assay mixture (16) was as follows: $0.25 \mathrm{~mm}$ NAD, an appropriate amount of the 
enzyme, $1 \mathrm{~mm}$ 2-mercaptoethanol, $4 \mathrm{~mm}$ sodium arsenate, $50 \mathrm{~mm}$ Tris- $\mathrm{HCl}$ buffer ( $\mathrm{pH} 8.6$ ) and $0.2 \mathrm{~mm}$ glyceraldehyde-3-phosphate in a final volume of $1.0 \mathrm{ml}$.

\section{RESULTS}

\section{Purification of transketolase from pig liver}

Figure 1 shows the elution profile of transketolase on a DEAE-cellulose column. Transketolase activity was found in the fractions from 17 to 30 , among which fraction 24 showed the highest specific activity. The transketolase was eluted slower than bulk protein. A concentrate of the combined fractions 19-27 was then applied to a Sephadex G-200 column. Figure 2 shows the elution profile. The proteins were eluted as one major peak (fraction 88 ) with two other small peaks while the enzyme activity appeared in only one peak (fraction 120). Table 1 shows

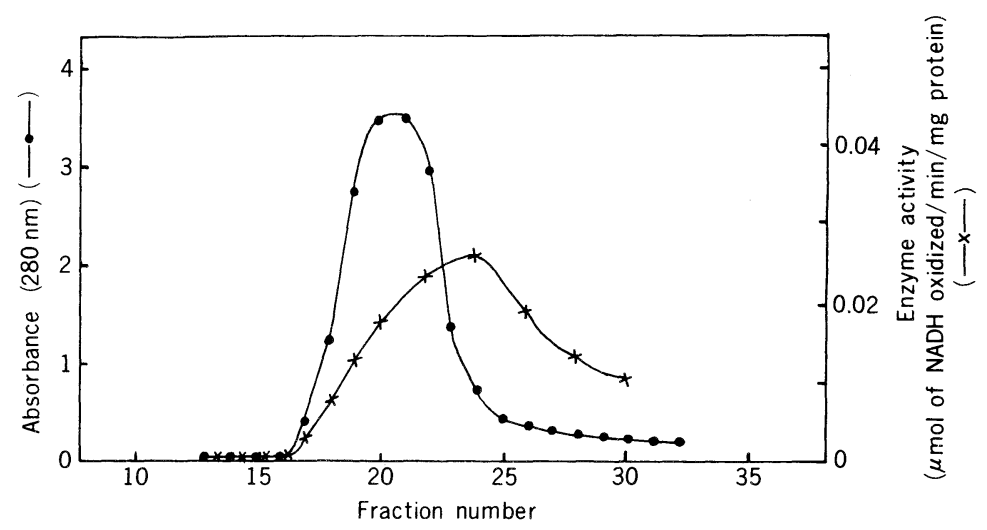

Fig. 1. Chromatography of pig liver transketolase on DEAE-cellulose column.

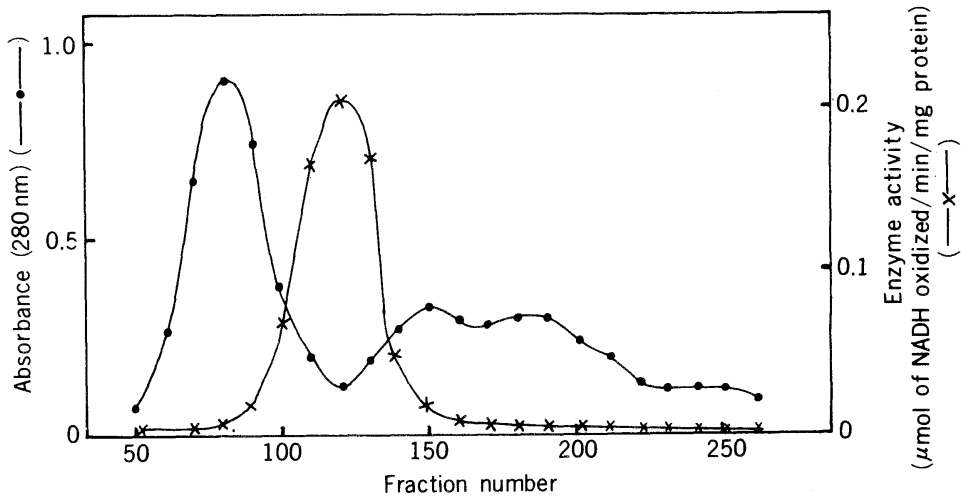

Fig. 2. Sephadex G-200 gel filtration of pig liver transketolase. 
Table 1. Summary of procedure for purification of transketolase from pig liver.

\begin{tabular}{lcccc}
\hline Fraction & $\begin{array}{c}\text { Total } \\
\text { volume } \\
(\mathrm{ml})\end{array}$ & $\begin{array}{c}\text { Total } \\
\text { protein } \\
(\mathrm{mg})\end{array}$ & $\begin{array}{c}\text { Specific } \\
\text { activity } \\
\text { (units/mg protein) }\end{array}$ & Purification \\
\hline Crude extract & 900 & 115200 & 0.0021 & 1 \\
$\left(\mathrm{NH}_{4}\right)_{2} \mathrm{SO}_{4}$ & 23 & 4830 & 0.0061 & 2.9 \\
DEAE-cellulose & 82 & 558 & 0.0180 & 8.6 \\
Sephadex G-200 & 3 & 0.49 & 0.2013 & 95.9 \\
\hline
\end{tabular}

$1 \mathrm{unit}=\mu \mathrm{mol}$ of $\mathrm{NADH}$ oxidized $/ \mathrm{min} / \mathrm{mg}$ protein at $37^{\circ} \mathrm{C}$.

Table 2. The activity of pig liver transketolase treated by three methods of resolution for cofactors.

\begin{tabular}{|c|c|c|c|c|c|}
\hline \multirow{2}{*}{$\begin{array}{l}\text { Resolu- } \\
\text { tion } \\
\text { method }^{\mathrm{a}}\end{array}$} & \multirow{2}{*}{$\begin{array}{l}\text { Incubation } \\
\text { medium }\end{array}$} & \multicolumn{2}{|c|}{$\begin{array}{c}\text { Activity } \\
(\mu \text { mol of } \mathrm{NADH} \text { oxidized/min/mg protein })\end{array}$} & \multirow{2}{*}{$\begin{array}{c}\frac{(\mathrm{B})}{(\mathrm{A})} \times 100 \\
(\%)\end{array}$} & \multirow{2}{*}{$\begin{array}{c}\text { Enzyme } \\
\text { resolved } \\
(\%)\end{array}$} \\
\hline & & $\begin{array}{l}\text { (A) with added TPP } \\
\text { and } \mathrm{CaCl}_{2}\end{array}$ & $\begin{array}{l}\text { (B) without added } \\
\text { TPP and } \mathrm{CaCl}_{2}\end{array}$ & & \\
\hline A & $\begin{array}{l}16 \mathrm{~mm} \text { EDTA-0.12 } \\
\mathrm{KCl}(\mathrm{pH} 7.4)\end{array}$ & 0.0856 & 0.0761 & 88.9 & 11.1 \\
\hline B & $\begin{array}{l}1.6 \mathrm{M}\left(\mathrm{NH}_{4}\right)_{2} \mathrm{SO}_{4} \\
(\mathrm{pH} 7.8)\end{array}$ & 0.118 & 0.0894 & 75.8 & 24.2 \\
\hline $\mathrm{C}$ & $\begin{array}{l}25 \mathrm{~mm} \text { glycylgly- } \\
\text { cine (pH 7.6) }\end{array}$ & 0.190 & 0.126 & 66.3 & 34.7 \\
\hline
\end{tabular}

${ }^{a}$ See text.

the change in the specific activity of the enzyme during purification. The enzyme preparation thus obtained gave two protein bands with Amide Black staining in acrylamide disc gel electrophoresis. One of them coincided with transketolase in its electrophoretic mobility. Another one which migrated faster than transketolase was assumed to be glyceraldehyde-3-phosphate dehydrogenase since the band was stained by nitroblue tetrazolium upon incubation at $30^{\circ} \mathrm{C}, \mathrm{pH} 8.6$, for 20 min with fructose diphosphate, NAD, phenazine methosulfate, sodium arsenate and aldolase (5). This was further supported by the fact that the Sephadex G-200 preparation (fraction 120) showed NAD-reducing activity at $\mathrm{pH} 8.6$ in the presence of glyceraldehyde-3-phosphate, 2-mercaptoethanol and sodium arsenate (16). Transketolase was fairly stable and about $95 \%$ of the enzyme activity remained for three months at $-20^{\circ} \mathrm{C}$ in $50 \mathrm{~mm}$ glycylglycine buffer ( $\mathrm{pH} 7.6$ ).

\section{Resolution of transketolase for cofactors}

The following three methods, which were employed by RACKER et al.(6), 
DATTA and RACKER (7) and OzAWA et al. (8) in the resolution of yeast transketolase, were applied to the resolution of pig liver transketolase. Purified pig liver transketolase $(4.8 \mathrm{mg}$ of protein) was dialyzed against $0.12 \mathrm{M} \mathrm{KCl}$ solution $(\mathrm{pH} 7.4)$ containing $16 \mathrm{~mm}$ EDTA for $48 \mathrm{hr}(6)$ (method A); dialyzed against $1.6 \mathrm{M}$ ammonium sulfate solution $(\mathrm{pH} 7.8)$ for $16 \mathrm{hr}(7)$ (method B); or kept in $25 \mathrm{~mm}$ glycylglycine buffer (pH 7.6) at $0^{\circ} \mathrm{C}$ for $48 \mathrm{hr}(8)$ (method $\mathrm{C}$ ) and the activity was assayed in the presence or absence of TPP $(0.1 \mathrm{mM})$ and $\mathrm{CaCl}_{2}(4.5 \mathrm{mM})$. As shown in Table 2, the enzyme treated by these three methods showed $66.3-88.9 \%$ of the holoenzyme activity even in the absence of added TPP and $\mathrm{CaCl}_{2}$. These methods

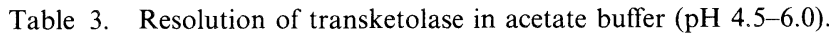

\begin{tabular}{|c|c|c|c|}
\hline \multirow{2}{*}{$\mathrm{pH}$} & \multicolumn{2}{|c|}{$\begin{array}{c}\text { Activity } \\
(\mu \mathrm{mol} \text { of } \mathrm{NADH} \text { oxidized } / \mathrm{min} / \mathrm{mg} \text { protein })\end{array}$} & \multirow{2}{*}{$\begin{array}{c}\text { Enzyme } \\
\text { resolved } \\
(\%)\end{array}$} \\
\hline & $\begin{array}{l}\text { with added TPP } \\
\text { and } \mathrm{CaCl}_{2}\end{array}$ & $\begin{array}{l}\text { without added TPP } \\
\text { and } \mathrm{CaCl}_{2}\end{array}$ & \\
\hline 6.0 & $0.186 \quad(100)$ & $0.146 \quad(78.5)$ & 21.5 \\
\hline 5.5 & $0.160 \quad(86.0)$ & $0.111 \quad(59.7)$ & 30.6 \\
\hline 5.0 & $0.0819(44.0)$ & $0.0358(19.2)$ & 56.3 \\
\hline 4.5 & $0.0488(26.2)$ & $0.0126(6.8)$ & 74.2 \\
\hline
\end{tabular}

Numbers in parentheses indicate percent of activities based on activity with added TPP and $\mathrm{CaCl}_{2}$ at $\mathrm{pH}$ 6.0.

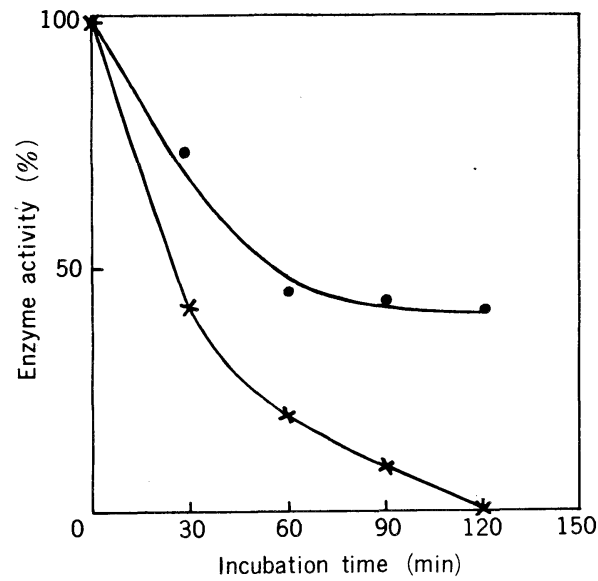

Fig. 3. Resolution of transketolase in acetate buffer ( $\mathrm{pH} 5.0)$. Transketolase (108 $\mu \mathrm{g}$ of protein) was added to $0.5 \mathrm{ml}$ of $0.2 \mathrm{M}$ acetate buffer $\left(\mathrm{pH} \mathrm{5.0)}\right.$ ) and was incubated at $0^{\circ} \mathrm{C}$ for the periods indicated. After the $\mathrm{pH}$ was adjusted to 7.5, each solution was gel filtered through a Sephadex G-25 column equilibrated with $50 \mathrm{~mm}$ glycylglycine buffer $(\mathrm{pH}$ 7.6). Enzyme activity was determined in the presence and absence of TPP $(1 \mathrm{mM})$ and $\mathrm{CaCl}_{2}(0.9 \mathrm{~mm}) .--$, With added TPP and $\mathrm{CaCl}_{2} ;-\times-$, without added TPP and $\mathrm{CaCl}_{2}$. 
were therefore not suitable for the resolution of transketolase from pig liver. We then tried using an acidic medium to resolve pig liver transketolase for cofactors. One $\mathrm{ml}$ of enzyme solution ( $4.8 \mathrm{mg}$ of protein) was kept at $0^{\circ} \mathrm{C}$ for $60 \mathrm{~min}$ in $1 \mathrm{ml}$ of $0.1 \mathrm{M}$ acetate buffer of different $\mathrm{pH}$ values $(\mathrm{pH} 4.5-6.0)$ and activities were determined with and without TPP $(0.1 \mathrm{mM})$ and $\mathrm{CaCl}_{2}(4.5 \mathrm{~mm})$ in the standard assay system. As shown in Table 3, the enzyme was stable at $\mathrm{pH} 6.0$ but it became unstable as the $\mathrm{pH}$ of the solution decreased. In contrast, the enzyme was resolved sufficiently at lower $\mathrm{pH}$ values. Figure 3 shows the resolution and inactivation of pig liver transketolase during incubation at $0^{\circ} \mathrm{C}$ in acetate buffer $(\mathrm{pH} 5.0)$. Good resolution was achieved after 60 min incubation, when the loss of enzyme activity became almost constant and the resolution proceeded progressively.

\section{Reconstitution of holoenzyme from resolved enzyme and cofactors}

The activity of transketolase was measured by incubating the resolved enzyme with various amounts of TPP $(10 \mathrm{nM}-5 \mu \mathrm{M})$ and $4.5 \mathrm{mM} \mathrm{CaCl}_{2}$ in $0.5 \mathrm{M}$ glycylglycine buffer ( $\mathrm{pH} 7.6)$ at $37^{\circ} \mathrm{C}$ for $20 \mathrm{~min}$. As shown in Fig. 4, the activity increased sigmoidally with increasing concentrations of TPP. The formation of holoenzyme was dependent on the $\mathrm{pH}$ value of the incubation medium. After the resolved enzyme was incubated with excess TPP $(0.1 \mathrm{mM})$ and $\mathrm{CaCl}_{2}(0.9 \mathrm{~mm})$ in either $40 \mathrm{~mm}$ acetate buffer ( $\mathrm{pH} 6.0-6.8$ ) or $40 \mathrm{~mm}$ glycylglycine buffer $(\mathrm{pH} 7.0-8.0)$ at $37^{\circ} \mathrm{C}$ for $5 \mathrm{~min}$, the excess cofactors were removed by gel filtration with a Sephadex G-25 equilibrated with the same buffer used for incubating the resolved enzyme. Enzyme activity was determined in the presence or absence of excess TPP and $\mathrm{CaCl}_{2}$. The results are shown in Fig. 5. The reconstitution of the holoenzyme was incomplete at

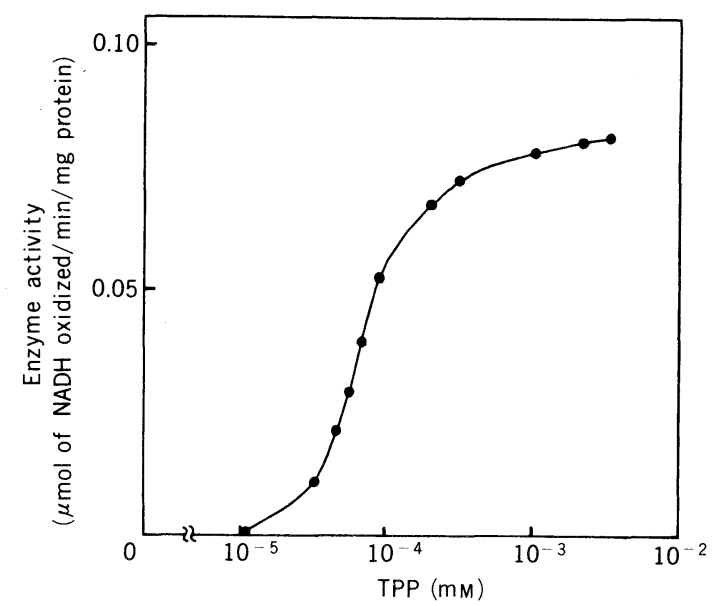

Fig. 4. The activity of transketolase as a function of TPP concentration. In a total volume of $1.0 \mathrm{ml}, 0.5 \mathrm{M}$ glycylglycine buffer $(\mathrm{pH} 7.6)$, resolved transketolase $(760 \mu \mathrm{g})$, TPP at various concentrations as indicated and $4.5 \mathrm{mM} \mathrm{CaCl}_{2}$ were incubated at $37^{\circ} \mathrm{C}$ for $20 \mathrm{~min}$. Enzyme activity was measured as mentioned in the experimental section. 


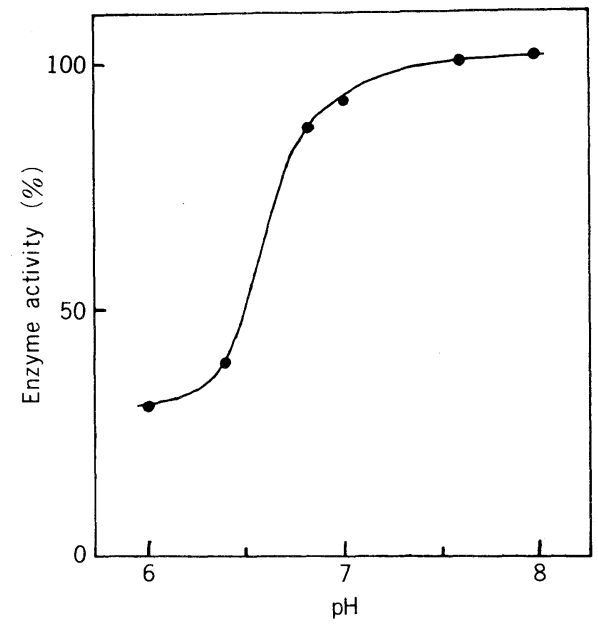

Fig. 5. Effect of the $\mathrm{pH}$ on reconstitution of resolved transketolase and cofactors. Resolved transketolase ( $3.3 \mathrm{mg}$ of protein) was incubated in $0.4 \mathrm{ml}$ of $50 \mathrm{~mm}$ acetate buffer ( $\mathrm{pH} 6.0,6.4$, 6.8 ) or $50 \mathrm{~mm}$ glycylglycine buffer ( $\mathrm{pH} 7.0,7.6,8.0$ ) with $0.05 \mathrm{ml}$ of $1 \mathrm{~mm} \mathrm{TPP}$ and $9 \mathrm{mM} \mathrm{CaCl}_{2}$ at $37^{\circ} \mathrm{C}$ for $5 \mathrm{~min}$. It was then gel filtered through a Sephadex G-25 column $(1 \times 30 \mathrm{~cm})$ equilibrated with the same buffer used for incubation of the sample. Enzyme activity was determined in the presence or absence of TPP (1 mM) and $\mathrm{CaCl}_{2}(0.9 \mathrm{mM})$.

pH 6.0 and 6.4; the enzyme showed only 31 and $40 \%$ of the full activity. But the reconstitution was almost complete at $\mathrm{pH} 7.6$ or above.

\section{DISCUSSION}

Transketolase from animal tissues is fairly unstable compared to that from yeast and a marked inactivation takes place as the process of purification becomes longer. The present study was conducted to purify transketolase from pig liver as rapidly as possible and to resolve the holoenzyme into apoenzyme and cofactors. As shown in Table 1, transketolase was purified 96-fold in a four-step purification process: extraction, ammonium sulfate fractionation, DEAE-cellulose column chromatography and Sephadex G-200 gel filtration. Transketolase preparations thus obtained showed a specific activity of $0.2 \mathrm{unit} / \mathrm{mg}$ of protein and contained glyceraldehyde-3-phosphate dehydrogenase. This enzyme is known to accompany transketolase from yeasts and human erythrocytes. Their separation has not been successful without a marked inactivation in the case of erythrocyte transketolase.

HORECKER et al. (9) reported that the enzyme from rat liver could be resolved by treatment with $0.076 \mathrm{~N} \mathrm{H}_{2} \mathrm{SO}_{4}$. SimpSON (10), however, reported that application of HORECKER's method to a preparation of transketolase from pig liver was unsuccessful. HeINRICH and Wiss (11) also reported that it was difficult to resolve transketolase from human erythrocytes with $0.076 \mathrm{~N} \mathrm{H}_{2} \mathrm{SO}_{4}$.

Transketolase from pig liver was fairly stable at $\mathrm{pH} 6.0$ and above, and full 
activity could be restored with the addition of excess cofactors. The transketolase was, however, unstable in a more acidic medium and inactivated by releasing TPP and metal ion, resulting in the formation of resolved enzyme which was further irreversibly inactivated. The rate of inactivation became greater as the $\mathrm{pH}$ decreased and thus transketolase, treated at $\mathrm{pH} 5.5$ and 4.5 , showed a 14.0 and $73.8 \%$ loss of activity, respectively, when assayed with excess TPP and $\mathrm{CaCl}_{2}$ at $\mathrm{pH} 6.0$. It must be noted, however, that the ratio of activity with and without cofactors increased as the $\mathrm{pH}$ decreased and the resolution of the enzyme became larger upon longer incubation (see Fig. 3). Transketolase from pig liver is thus quite different from that from yeast enzyme as the latter can be resolved only at pH 7.0 and above $(17,18)$.

The difference between transketolase from pig liver and that from yeasts was also observed in the reconstitution experiments. Resolved transketolase from pig liver could be reconstituted at neutral $\mathrm{pH}$ and above but not in an acidic medium, while that from yeasts were reconstituted in weakly acidic media ( $\mathrm{pH} 6.0-5.0)$ but not in alkaline media ( $\mathrm{pH} 7.0-9.0)(18,19)$. The binding mode of TPP and metal ion on apoenzymes from the two sources are thus apparently different.

\section{REFERENCES}

1) DAtTA, A. G., and RACKeR, E. (1961): Mechanism of action of transketolase. II. The substrateenzyme intermediate. J. Biol. Chem., 236, 624-628.

2) Saitou, S., Ozawa, T., and Tomita, I. (1974): The purification and some properties of brewer's yeast apotransketolase. FEBS Lett., 40, 114-118.

3) Heinrich, C. P., and Wiss, O. (1971): Subunit size of transketolase from baker's yeast. FEBS Lett., 14, 251-253.

4) Haba, D. L., Leder, I., and RACKer, E. (1955): Crystalline transketolase from baker's yeast; Isolation and properties. J. Biol. Chem., 214, 409-426.

5) Kochetov, G. A., Nikitushrina, L. I., and Chernov, N. N. (1970): A complex of functionallybound enzyme; Transketolase and glyceraldehyde phosphate dehydrogenase. Biochem. Biophys. Res. Commun., 40, 873-879.

6) RACKer, E., HABA, D. L., and Leder, I. G. (1953): Thiamine pyrophosphate, A coenzyme of transketolase. J. Am. Chem. Soc., 75, 1010-1011.

7) Datta, A. G., and Racker, E. (1961): Mechanism of action of transketolase. I. Properties of the crystalline yeast enzyme. J. Biol. Chem., 236, 617-623.

8) Ozawa, T., Saitou, S., and Tomita, I. (1971): The coenzyme activities of 2 '-substituted thiamine derivatives. II. The activities of $2^{\prime}$-northiamine and $2^{\prime}$-ethylthiamine as coenzyme for apotransketolase. Vitamins, 44, 303-307.

9) Horecker, B. L. Smyrniotis, P. Z., and Klenow, H. (1953): The formation of sedoheptulose phosphate from pentose phosphate. J. Biol. Chem., 205, 661-682.

10) Simpson, F. J. (1960): Preparation and properties of transketolase from pork liver. Can. J. Biochem. Physiol., 38, 115-124.

11) HeinRich, P. C., and Wiss, O. (1971): Transketolase from human erythrocytes; Purification and properties. Helv. Chim. Acta, 54, 2658-2668.

12) Johnson, L. R., and GUbler, C. J. (1968): Studies on the physiological function of thiamine. III. The phosphorylation of thiamine in brain. Biochem. Biophys. Acta, 156, 85-96.

13) Ashwell, G., and Hickman, J. (1957): Enzymatic formation of xylulose-5-phosphate from ribose-5-phosphate in spleen. J. Biol. Chem., 226, 65-75.

14) Davis, B. J. (1964): Disc electrophoresis. II. Method and application to human serum 
proteins. Ann. N.Y. Acad. Sci., 121, 404-427.

15) Lowry, O. H., Rosebrough, N. J., Farir, A. L., and Randall, R. J. (1953): Protein measurement with the Folin phenol reagent. J. Biol. Chem., 193, 265-275.

16) Oguchi, M. (1970): Glyceraldehyde-3-phosphate dehydrogenase from human erythrocytes. $J$. Biochem., 68, 427-439.

17) Kochetov, G. A., and Izotova, A. E. (1970): Conditions of elimination of thiamine pyrophosphate from holotransketolase. Biokhimiya, 35, 1023-1027.

18) Tomita, I., and SaItou, S., Unpublished results.

19) Heinrich, P. C., Steffen, H., Janser, P., and Wiss, O. (1972): Studies on the reconstitution of apotransketolase with thiamine pyrophosphate and analogs of the coenzyme. Eur. J. Biochem., 30, 533-541. 